\title{
AIDS in adults 50 years of age and over: characteristics, trends and spatial distribution of the risk ${ }^{1}$
}

\author{
Jordana de Almeida Nogueira² \\ Antônia Oliveira Silva ${ }^{3}$ \\ Laísa Ribeiro de Sá4 \\ Sandra Aparecida de Almeida $^{5}$ \\ Aline Aparecida Monroe ${ }^{6}$ \\ Tereza Cristina Scatena Villa ${ }^{7}$
}

Objective: to analyze the sociodemographic characteristics, epidemic trend and spatial distribution of the risk of AIDS in adults 50 years of age and over. Method: population-based, ecological study, that used secondary data from the Notifiable Disease Information System (Sinan/AIDS) of Paraíba state from the period January 2000 to December 2010. Results: during the study period, 307 cases of AIDS were reported among people 50 years of age or over. There was a predominance of males $(205 / 66,8 \%)$, mixed race, and low education levels. The municipalities with populations above 100 thousand inhabitants reported $58.5 \%$ of the cases. There was a progressive increase in cases among women; an increasing trend in the incidence (positive linear correlation); and an advance in the geographical spread of the disease, with expansion to the coastal region and to the interior of the state, reaching municipalities with populations below 30 thousand inhabitants. In some locations the risk of disease was 100 times greater than the relative risk for the state. Conclusion: aging, with the feminization and interiorization of the epidemic in adults 50 years of age and over, confirms the need for the induction of affirmative policies targeted toward this age group.

Descriptors: Acquired Immunodeficiency Syndrome; Aging; Epidemiology.

\footnotetext{
${ }^{1}$ Supported by Programa Nacional de Cooperação Acadêmica (Procad) from Universidade Federal da Paraíba and by Coordenação de Pessoal de Nível Superior (CAPES) process \# 2878/2008.

${ }^{2}$ PhD, Adjunct Professor, Departamento de Enfermagem Clínica, Centro de Ciências da Saúde, Universidade Federal da Paraíba, João Pessoa, PB, Brazil. ${ }^{3} \mathrm{PhD}$, Associate Professor, Departamento de Enfermagem em Saúde Publica e Psiquiatria, Centro de Ciências da Saúde, Universidade Federal da Paraíba, João Pessoa, PB, Brazil.

${ }^{4}$ Master's student, Departamento de Estatística, Centro de Ciências Exatas e da Natureza, Universidade Federal da Paraíba, João Pessoa, PB, Brazil. ${ }_{5}^{5}$ Doctoral student, Departamento de Enfermagem, Centro de Ciências da Saúde, Universidade Federal da Paraíba, João Pessoa, PB, Brazil. Professor, Faculdade de Enfermagem Nova Esperança, João Pessoa, PB, Brazil. Scholarship holder from Coordenação de Aperfeiçoamento de Pessoal de Nível Superior (CAPES).

${ }^{6} \mathrm{PhD}$, Professor, Escola de Enfermagem de Ribeirão Preto, Universidade de São Paulo, WHO Collaborating Centre for Nursing Research Development, Ribeirão Preto, SP, Brazil.

${ }^{7}$ PhD, Full Professor, Escola de Enfermagem de Ribeirão Preto, Universidade de São Paulo, WHO Collaborating Centre for Nursing Research Development, Ribeirão Preto, SP, Brazil.
}

Corresponding Author:

Jordana de Almeida Nogueira

Universidade Federal da Paraíba. Centro de Ciências da Saúde

Departamento de Enfermagem Clínica

Cidade Universitária

CEP: 58051-900, João Pessoa, PB, Brasil

E-mail: jalnogueira31@gmail.com
Copyright @ 2014 Revista Latino-Americana de Enfermagem This is an Open Access article distributed under the terms of the Creative Commons Attribution Non-Commercial License (CC BY-NC).

This license lets others distribute, remix, tweak, and build upon your work non-commercially, and although their new works must also acknowledge you and be non-commercial, they don't have to license their derivative works on the same terms. 


\section{Introduction}

Over thirty years infection with the human immunodeficiency virus (HIV) has spread worldwide, reaching individuals irrespective of age and sex. Although it was originally considered a disease confined to certain groups, the wide spread and diversity in the distribution patterns have determined distinct configurations in the epidemiological scenario. There is expansion among the economically most vulnerable, acceleration in the number of cases in smaller municipalities, with the spread of the epidemic among adolescents, men who claim to be heterosexual, among women, and older adults ${ }^{(1-6)}$.

Although most cases of HIV infection are detected in the age group 15 to 49 years, the progressive increase in morbidity and mortality due to the Human Immunodeficiency Syndrome (AIDS) in the age group over 50 years has been portrayed globally and become relevant in countries with a high rate of population aging. According to the United Nations Organization for the Prevention and Control of AIDS, it is estimated that of the 40 million people living with HIV/AIDS worldwide, approximately 2.8 million are in the same age group greater as this populational segment(7).

In the United States, between 2001 and 2005, the estimated number of cases of AIDS by age at diagnosis increased by approximately $40 \%$ in people 50 years of age or over, and currently approximately $29 \%$ of the people living with AIDS, are in this age group $^{(8)}$. In Canada $12.4 \%$ of all the cases of AIDS reported occurred in people 50 years of age or over. The proportion of positive HIV tests among those 50 years of age or over increased from $10.6 \%$ in 1999 to $15.3 \%$ in $2008^{(9)}$. The prevalence of HIV in South Africa in the $50-54$ years age group was $10.8 \%, 4.5 \%$ among the 55-59 years age group, and 3.9\% among those 60 years of age and $\operatorname{over}^{(7)}$.

In Brazil 76,618 cases of AIDS in people 50 years of age or over were reported in the Notifiable Disease Information System (Sinan) and declared in the Mortality System (SIM) during the period from 1980 to 2012, with 49,135 cases occurring in males and 27,483 in females. Over the period 1998 to 2012, in both sexes 50 years of age and over, the incidence rate increased by $60 \%$. Among the women 50 to 59 years of age, there was a higher incidence of 9.5 to 18.4 cases per 100 thousand inhabitants ${ }^{(10)}$.

In the Northeastern region, 7,423 cases of AIDS in people 50 years of age or over were reported in the Notifiable Disease Information System (Sinan) and declared in the Mortality System (SIM) during the period from 1980 to 2012, with 5,183cases occurring in males and 2,240in females. The incidence rate among males rose from 2.2 to 4.4 cases per 100 thousand inhabitants between 1998 and 2010 and among women from 0.6 to 1.5 cases per 100 thousand over the same period ${ }^{(10)}$.

The observed trend shows a gradual progression of the incidence of the disease among older adults, with expansion evident in the females. Numerous studies conducted in Brazil(2,6,11-13) have identified changes in the epidemic pattern of the disease, however, they emphasize the analysis of nationally consolidated information. However, there is a consensus that studies with greater disaggregation allow, "specific contexts to be comprehended, which consequently subsidizes local policies, reinforcing the responsibility of the municipalities in the organization of the health promotion and care network"(6). In this respect, a state in the Northeastern region was selected for this study, with a high rate of population aging, in which the population of 50 years of age and over represented $20.5 \%$ of the total population. Despite the small land area, the state of Paraíba ranks ninth among the federal units, presenting a high concentration of municipalities (223), with $92 \%$ of these having populations of less than 30 thousand inhabitants. It should be added that $20.2 \%$ of the population is illiterate and $16.3 \%$ lives in situations of extreme poverty ${ }^{(14)}$. This context shows conditions that potentially favor the phenomenon of interiorization, aging and impoverishment of AIDS, requiring that it be analyzed considering its particularity. Therefore, this study considers the cases reported in Paraíba, during the period 2000 to 2010, with the aim of analyzing the sociodemographic characteristics, epidemic trend, and spatial distribution of the risk of AIDS in adults 50 years of age and over.

\section{Methods}

This ecological, time series study was performed based on the records of cases of AIDS originating from the 223 municipalities of Paraíba. The state has a population of $3,766,528$ inhabitants, and is administratively organized into four mesoregions. The data collection took place in December 2012, and all the confirmed cases of AIDS reported in the Notifiable Disease Information System (Sinan) database over the period from $1^{\text {st }}$ January 2000 to $31^{\text {st }}$ December 2010 were included in the study. Of the total of 2,904 cases reported in Sinan, 307 cases that met the following 
criteria were selected for the study: to be 50 years of age or over; to be a resident in the state of Paraíba.

The data were arranged in an Excel spreadsheet and a refinement of the database was performed to identify the variables of interest: gross number of cases per month, age group, race/color, education, gender, epidemiological year, municipality of residence, sexual practice. The data were checked for consistency, encoded and subsequently transferred to the Statistic 12.0 program. The cases of AIDS among adults 50 years of age and over, were analyzed according to the year of notification and gender, involving measures of percentage frequency and gender ratio. The chi squared test of association $\left(\chi^{2}\right)$ was used to analyze the association between the sociodemographic variables, with $p$ values $\geq 0.05$ being considered statistically significant.

For optimal visualization of the epidemic trend of the state, the technique of linear regression was applied and the annual incidence rates of cases of AIDS in the general population and in individuals 50 years of age and over were calculated, using the populational base of 100 thousand inhabitants. The incidence rate of the municipalities was calculated considering the year of notification and a populational base of one thousand inhabitants. In both situations the denominators were estimated from geometric interpolations of the population of Paraíba obtained from the Brazilian Demographic Census conducted in 2000 and 2010 and from the data of the National Household Sample Survey (PNAD).

The calculation of Relative Risk (RR) was based on the ratio of the incidence rate of each municipality according to the incidence rate in the state. Integrating the Excel and $\mathrm{R}$ programs (The $\mathrm{R}$ Foundation for Statistical Computing) allowed the generation of choropleth maps to spatially represent the RR and the identification of municipalities that presented the highest and lowest risks of disease occurrence. The RR was divided into class intervals, with a previously established color used for each interval. For the interpretation of the RR map the following criteria were defined: $<0.5=R R$ of the event less than half the overall risk of the state; 0.5 to $1.0=R R$ of the event greater than half the overall risk of the state; 1.0 to $2.0=R R$ of the event greater than the overall risk of the state of less than $100 \% ; 2.0$ to $3.0=R R$ of the event greater than the overall risk of the state of more than $100 \%$ and less than $200 \%$; 3.0 or more=RR of the event greater than the overall risk of the state of more than $200 \%$.

The study was approved by the Research Ethics Committee (CEP) of the Federal University of Paraíba, under protocol number 612/10.

\section{Results}

During the period from 2000 to 2010, 307 cases of AIDS among people 50 years of age or over were reported to the STD/AIDS State Coordination of Paraíba. In 2009 the highest absolute number of cases was recorded (59/19.2\%). There was a predominance of males (205/66.8\%), with the proportion of cases between the genders (Ratio: Male/Female) in 2000 of 8.5:1, which reached $1.1: 1$ in 2007 (Table 1), remaining below $2: 1$ in the following years.

Table 1 - Distribution of AIDS cases among adults 50 years of age and over according to gender and year of notification. Paraíba, Brazil, 2000 to 2010

\begin{tabular}{|c|c|c|c|c|c|c|c|}
\hline \multirow{3}{*}{ Year } & \multicolumn{4}{|c|}{ Gender } & \multirow{2}{*}{\multicolumn{2}{|c|}{ Total }} & \multirow{3}{*}{ Ratio } \\
\hline & \multicolumn{2}{|c|}{ Male } & \multicolumn{2}{|c|}{ Female } & & & \\
\hline & $\mathbf{n}$ & $\%$ & $\mathbf{n}$ & $\%$ & $\mathbf{N}$ & $\%$ & \\
\hline 2000 & 17 & 8.3 & 02 & 02 & 19 & 6.2 & $8.5: 1$ \\
\hline 2001 & 11 & 5.4 & 05 & 4.9 & 16 & 5.2 & \\
\hline 2002 & 07 & 3.4 & 03 & 2.9 & 10 & 3.3 & \\
\hline 2003 & 14 & 6.8 & 03 & 2.9 & 17 & 5.5 & \\
\hline 2004 & 18 & 8.8 & 07 & 6.9 & 25 & 8.2 & \\
\hline 2005 & 13 & 6.3 & 08 & 7.8 & 21 & 6.8 & \\
\hline 2006 & 20 & 9.8 & 10 & 9.8 & 30 & 9.8 & \\
\hline 2007 & 17 & 8.3 & 15 & 14.7 & 32 & 10.4 & 1.1:1 \\
\hline 2008 & 19 & 9.3 & 12 & 11.8 & 31 & 10.1 & $1.58: 1$ \\
\hline 2009 & 38 & 18.5 & 21 & 20.6 & 59 & 19.2 & $1.80: 1$ \\
\hline 2010 & 31 & 15.1 & 16 & 15.7 & 47 & 15.3 & $1.93: 1$ \\
\hline Total & 205 & 100 & 102 & 100 & 307 & 100 & \\
\hline
\end{tabular}


The sociodemographic analysis revealed the similarity of proportions and the lack of association between the gender and education variables ( $p$-value $=0.3188)$. Approximately $50.0 \%$ of the cases were concentrated in the "without schooling" or "up to 3 years of study" categories (Table 2). A prevalence of mixed race individuals was observed in both genders $(p$-value $=0.2369)$.

Table 2 - Distribution of AIDS cases among adults 50 years of age and over according to gender and sociodemographic variables. Paraíba, Brazil, 2000 to 2010

\begin{tabular}{|c|c|c|c|c|c|}
\hline \multirow{3}{*}{ Variables } & \multicolumn{4}{|c|}{ Gender } & \multirow{3}{*}{$\mathbf{P}$} \\
\hline & \multicolumn{2}{|c|}{ Male } & \multicolumn{2}{|c|}{ Female } & \\
\hline & $n$ & $\%$ & $\mathbf{n}$ & $\%$ & \\
\hline \multicolumn{6}{|l|}{ Years of study } \\
\hline None & 45 & 22.0 & 26 & 25.5 & \multirow{6}{*}{0.3188} \\
\hline 1 to 3 & 47 & 23.0 & 29 & 28.4 & \\
\hline 4 to 7 & 38 & 18.5 & 23 & 22.5 & \\
\hline 8 to 11 & 40 & 19.5 & 15 & 14.7 & \\
\hline$\geq 12$ & 20 & 9.7 & 05 & 4.9 & \\
\hline Unanswered & 15 & 7.3 & 04 & 3.9 & \\
\hline \multicolumn{6}{|l|}{ Race/color } \\
\hline White & 56 & 27.3 & 26 & 25.5 & \multirow{5}{*}{0.2369} \\
\hline Mixed race & 107 & 52.2 & 59 & 57.8 & \\
\hline Black & 12 & 5.9 & 06 & 5.9 & \\
\hline Other & 04 & 1.9 & 05 & 4.9 & \\
\hline Unanswered & 26 & 12.7 & 06 & 5.9 & \\
\hline \multicolumn{6}{|l|}{ Municipalities } \\
\hline$<30$ thousand inhabitants & 56 & 27.3 & 32 & 31.4 & \multirow{3}{*}{0.4959} \\
\hline 30 to 100 thousand inhabitants & 29 & 14.2 & 10 & 9.8 & \\
\hline$>100$ thousand inhabitants & 120 & 58.5 & 60 & 58.8 & \\
\hline Sexual Practice & & & & & 0.0000 \\
\hline Heterosexual & 130 & 63.4 & 90 & 88.2 & \\
\hline Homosexual & 22 & 10.7 & 01 & 1.0 & \\
\hline Bisexual & 14 & 6.8 & - & - & \\
\hline Unanswered & 39 & 19.1 & 11 & 10.8 & \\
\hline Total & 205 & 100.0 & 102 & 100.0 & \\
\hline
\end{tabular}

Regarding the distribution of cases of AIDS throughout the municipalities of Paraíba, there were no significant differences between the genders, when compared to the different populational strata. Although the municipalities with population above 100 thousand inhabitants were responsible for $58.5 \%$ of the notifications, the smaller municipalities with less than 30 thousand inhabitants stood out due to them being responsible for $29.0 \%$ of the notifications, in both genders.

The use of the association test, with a significance level of $5 \% \quad(\alpha=0.05)$, revealed the similarity of proportions and the lack of association between the gender variable and the variables that comprised the sociodemographic profile (years of schooling, race/ color, population density of the municipality), except for the sexual practice variable $(p$-value $=0.0000)$. It was observed that heterosexual practice was predominant among the women.
Regarding the epidemic trend of the state (Figure 1), an increased incidence in the population 50 years of age and over was observed throughout the years of the study, with a greater dispersion in 2009 (8.3). When applying the linear regression technique to calculate the trend line, a positive slope was verified in the population 50 years of age and over, i.e., the starting point of the line was 1.9 and its end point was 6.3. This equates to a growth trend of approximately $232 \%$ in just over 10 years. In the general population there was little variation, with growth of $5 \%$.

In relation to the intensity of the occurrence of cases of AIDS in the population 50 years of age and over, expressed by relative risk (RR), it can be observed in Figure 2 that in the period 2000-2004, the highest RR values were concentrated in municipalities with higher population densities, dispersed in the Mata Paraibana (coastal region), Agreste and Sertão Mesoregions. From 
2007 , there was a concentration of cases of aids in the entire coastal region, reaching the small municipalities, a situation that persisted until 2010. In the Borborema (central) Mesoregion, three municipalities (with less than 30 thousand inhabitants) presented, over the period, a RR three times greater than the value of the state.

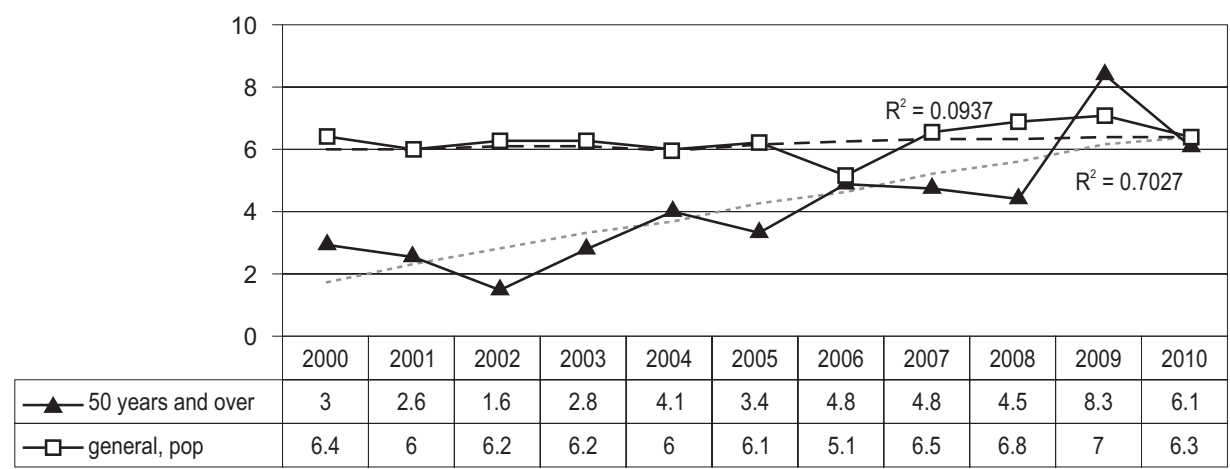

$\longrightarrow 50$ years and over $\quad \longrightarrow-$ general, pop $\quad$ - - - - - Linear (50 years and over) - - - Linear (general, pop)

Figure 1 - Incidence and linear trend of AIDS in individuals 50 years of age and over and in the general population. Paraíba, Brazil, 2000 to 2010
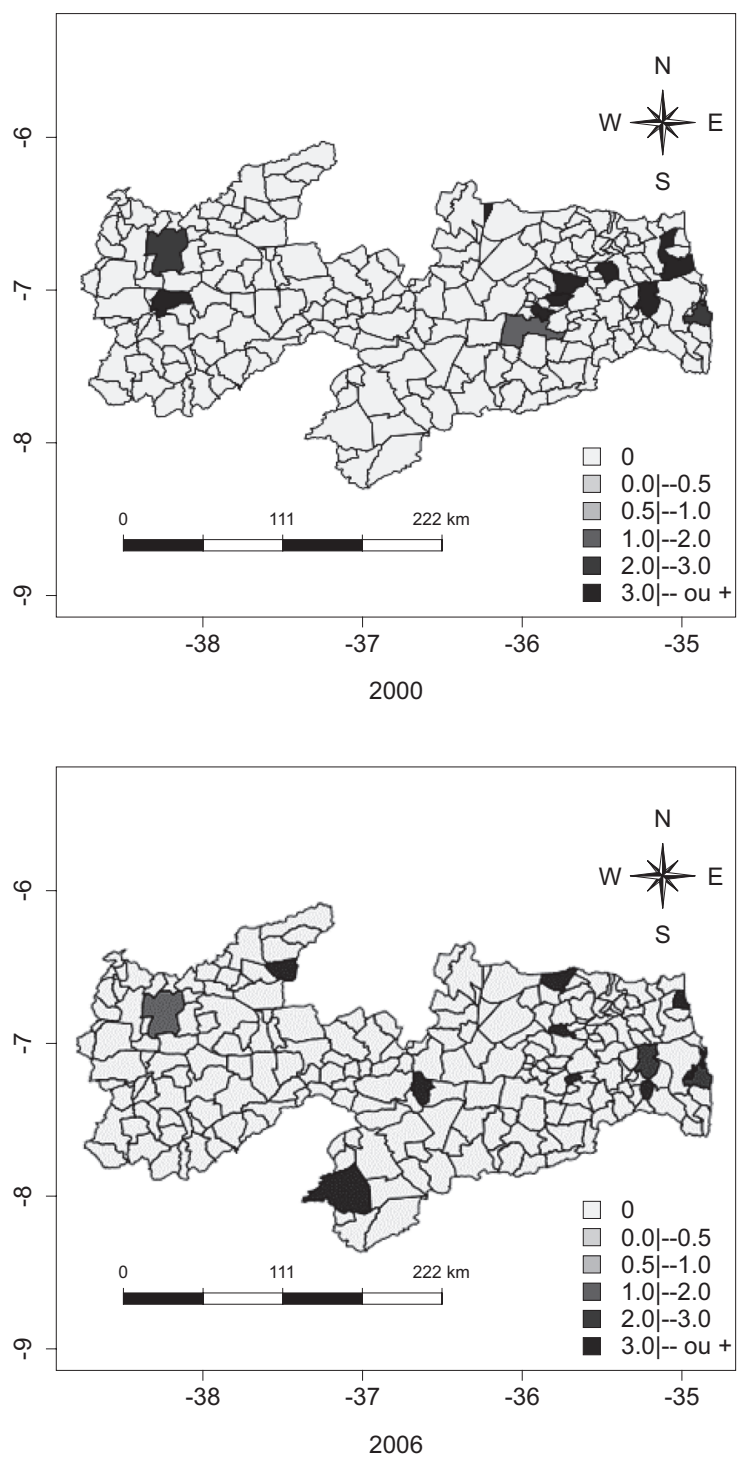
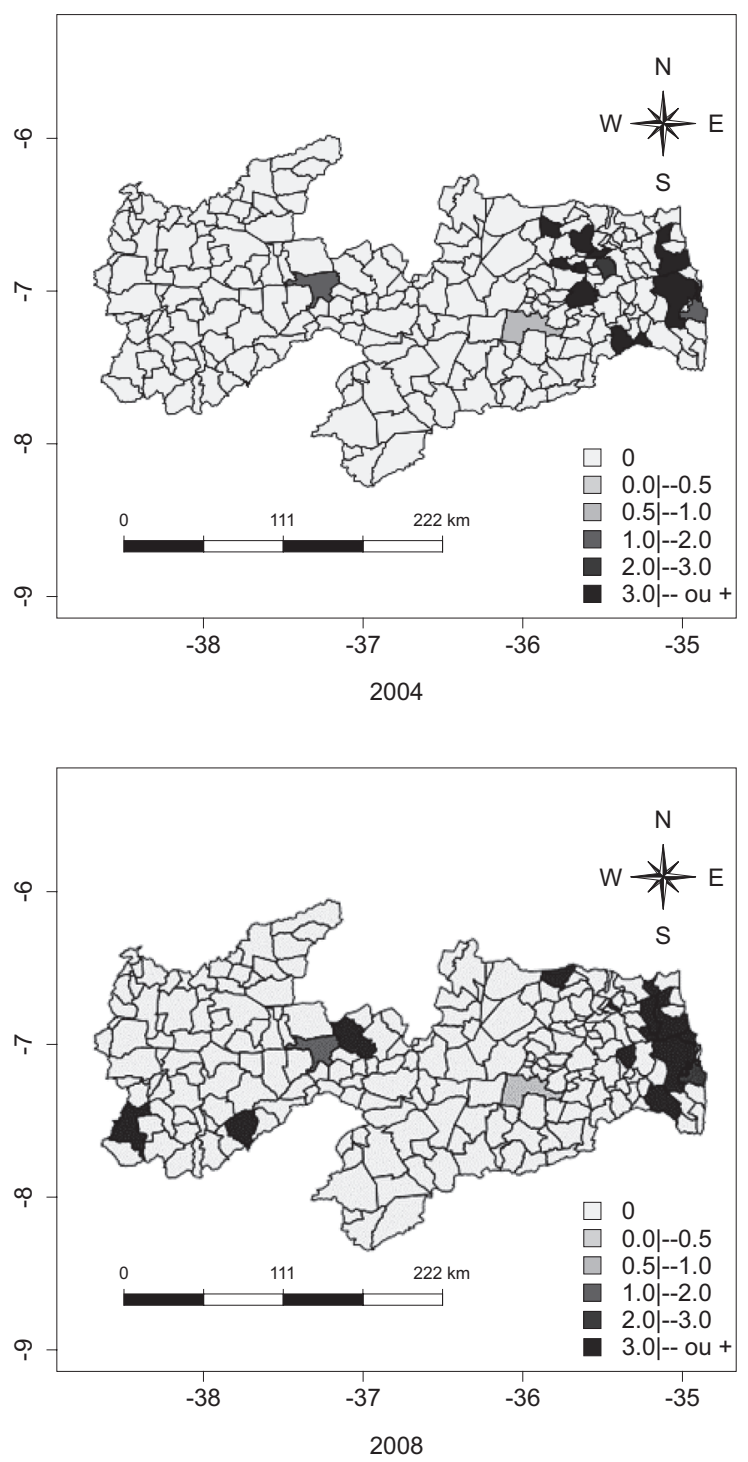

(The Figure 2 continue in the next page...) 

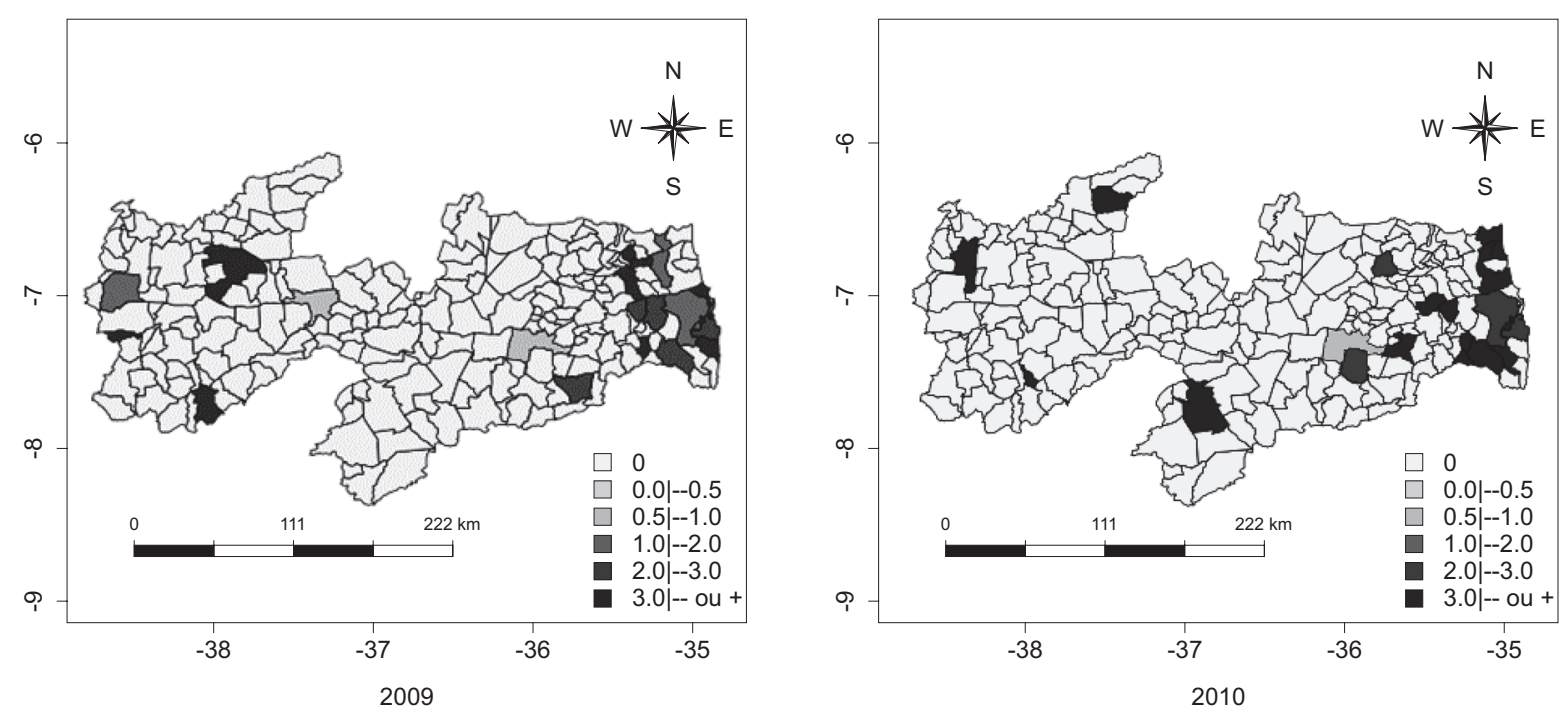

Figure 2 - Maps of the Relative Risk of AIDS in adults 50 years of age and over in the state of Paraíba, Brazil, 2000 to 2010

\section{Discussion}

In the historical series studied a greater proportion of cases of AIDS were identified in the male population, with a gradual increase among women. The decrease in the magnitude of the ratio between the genders confirms the trend of the feminization of the epidemic in the country as well as among the elderly. In the international scenario, women represent about $50 \%$ of all infected people. Sub-Saharan Africa is home to $76 \%$ of all women with HIV, and for every four seropositive young people (from 15 to 24 years) three are female. In other continents the proportion of infected women is increasing. In the Caribbean this exceeds $51 \%$ of the adults; in the Bahamas 59\%, in Trinidad and Tobago $56 \%$, in the Ukraine $46 \%$, and in Asia 30\%, reaching $46 \%$ in Cambodia and 39\% in Thailand ${ }^{(15)}$.

Studies indicate that the increase in cases among women is due to historical-cultural determinants and uneven valorization that is expressed in different ways, including domestic, sexual, moral, and patrimonial violence; the sexual division of labor; ethnic and racial inequality, poverty, stigma, and human rights violations; and the impossibility for women to independently negotiate their pleasure and the way they wish to express and experience their sexuality ${ }^{(16-18)}$. The existence of an asymmetry of power in the relationships between men and women, combined with inequalities in gender relationships in the social and economic spheres (less access to education and jobs for women, low wages and double shifts) end up determining a situation of extreme vulnerability for women to the AIDS epidemic ${ }^{(4)}$.

In the category race/color, the most affected by the disease were mixed race individuals, predominant in all the years of the study. A different result would not be expected, since, specifically in the state of Paraíba, over $50 \%$ of the population is of mixed ethnicity. The number of questions unanswered in this variable $(10.4 \%)$ is noteworthy, as this was information that was included on the report form from 2001. Although there has been an expressive completion of this variable from 2003, a study conducted in Brazil, in the period 2000 to 2005, verified a proportional decrease in the percentage of cases of AIDS among white individuals, a proportional increase in the number of cases among mixed race people (from $22.7 \%$ to $31.9 \%$ ), and stability among black people (approximately $11 \%$ to $13 \%)^{(11)}$. The displacement of the epidemic to the mixed race population could indicate that the increase in this group was associated with impoverishment of the disease and difficulty in access to the healthcare services(19-20).

With regard to education, this being the variable considered to have the greater explanatory power for the social differences(12-13), it was found that the proportion of cases with no formal education and with up to 3 years of study corresponded to $48.8 \%$. A higher level of education was verified among the men, with them better represented in the "high school" or "higher education" categories. In a study carried out in Santa Catarina, over $75 \%$ of cases had completed the $1^{\text {st }}$ or 
$2^{\text {nd }}$ school grades ${ }^{(21)}$. In the state of Espírito Santo Brazil, the education level varied depending on age, with an educational level of 4 to 7 years of schooling prevalent among the younger individuals, and a higher frequency of illiteracy among the older people(20).

In contrast, a study conducted in the national territory that evaluated a historical series from 2000 to 2005 found that the proportion of patients with no formal education remained more or less stable over the period(11). However, the percentage of cases of individuals with elementary education halved over the same period (from $39.4 \%$ to $18.6 \%$ ), and there was a substantial increase in cases occurring in people with high school or higher education (54.8\% to $76.4 \%)^{(11)}$. These data contradict the claim that the epidemic was increasing at a proportionally higher rate among the more socioeconomically vulnerable populations. It should be highlighted that among the federal regions, the South and Southeastern regions have the majority of cases and have a higher level of education. Whereas, in the state of Paraíba $20.2 \%$ of the population 15 years of age and over are illiterate, presenting the third worst literacy rate in the country ${ }^{(14)}$.

Regarding the incidence, a higher growth trend was observed in the population 50 years of age and over, when compared to the general population over the same period. This observation combines multiple determinants, which could be explained by sociocultural aspects (gender and generational asymmetry, disadvantage in the economic sphere, insufficient information about the disease, low perception of risk, and unprotected sex) (22), and the barriers imposed by the healthcare services (invisibility of this age group as potentially vulnerable, and inability of the team to suspect and diagnose the disease).

The socially naturalized concept of desexualization in the older ages, as a phase marked by inactivity and lack of sexual desire, ensures that this group is practically forgotten and left out of the policies and preventive priorities. The practical results of such a concept affect the misperception of their condition of invulnerability, the low demand for HIV testing, and possibly the underestimation of cases of AIDS in this age group(23).

The growth of the epidemic among older adults is also portrayed by its potential for dissemination. In the first four years investigated, it was observed that cases remained confined to the higher population density cities. In these locations, the RR showed variations between 3 and 4 times higher than the overall risk of the state. From 2004, there was a greater geographical spread of the disease, towards the small municipalities with less than 30 thousand inhabitants, which indicates the dynamics of interiorization of the disease. From 2007 to 2010 there was a more intense growth of the epidemic in the municipalities of the coastal region and close to João Pessoa, the state capital. This municipality may have the role of the diffusion center of HIV in the region. Among the possibilities for the spread of epidemics in the space, diffusion through contiguity and hierarchical diffusion by networks are mentioned(24). The frequency of interactions between inhabitants of surrounding areas and the capital favored the spread by contiguity. However, the importance of João Pessoa as the economic, technological and educational hub demands the intense movement of people, encouraging connections between distant municipalities in a hierarchical diffusion process.

\section{Conclusion}

The results of this study indicate a gradual increase in the number of cases of AIDS among the population 50 years of age and over, in Paraiba, predominantly in people of mixed race, with low education and heterosexual. The reduction of the magnitude of the ratio between the genders strengthens the condition of feminization of the epidemic and convokes concrete initiatives in state and municipal areas, which consider the local specificities and translate solutions for overcoming the different contexts of vulnerability of the older women.

The increased incidence among older adults and the advance in the geographical spread of the disease, with expansion into the coastal region and the interior of the state, reaching the small municipalities, are indicators that can potentially assist healthcare professionals and managers to establish priorities for the control of AIDS. The identification of municipalities with higher risk of illness and its representation in choropleth maps provides information that can support decision making and assist the local management in the performance/ implementation and/or optimization of actions.

The aging, feminization and interiorization of the epidemic in adults 50 years of age and over, confirm the need for the induction of affirmative policies targeted toward this age group. The prevention and health education actions should be redesigned by the multidisciplinary teams, so that they recognize the existence of sexual practice 
at this stage of life and consider the specificities inherent to it. Aspects of the sexuality, the gender, self-care, the use of condoms, and encouraging rapid testing should be incorporated into the practice of the healthcare professionals and addressed in the spaces of coexistence, home visits, and medical and nursing consultations.

\section{References}

1. Camargo BV, Bertoldo RB. Comparação da vulnerabilidade em relação ao HIV de estudantes da escola pública e particular. Estudos Psicol. 2006;23(4):369-79.

2. Pinto ACS, Pinheiro PNC, Vieira NFC, Alves MDS. Compreensão da pandemia da aids nos últimos 25 anos. J Bras Doenças Sex Transm. 2007;19(1):45-50.

3. Pottes FA, Brito AM, Gouveia GC, Araújo EC, Carneiro RM. Aids e envelhecimento: características dos casos com idade igual ou maior que 50 anos em Pernambuco, de 1990 a 2000. Rev Bras Epidemiol. 2007; 10(3):338-51.

4. Souza Z, Leite JL. Aids e envelhecimento: reflexões sobre a infecção pelo HIV em indivíduos acima dos 60 anos [Internet]. 2008. [acesso 16 out 2012]. Disponível em: http://www.saude.rio.rj.gov.br/saude/pubsms/media/ aidsenvelhecimento.doc

5. Reis CT, Czeresnia D, Barcellos C, Tassinari WS. A interiorização da epidemia de HIV/AIDS e o fluxo intermunicipal de internação hospitalar na Zona da Mata, Minas Gerais, Brasil: uma análise espacial. Cad Saúde Pública. 2008;24(6):1219-28.

6. Grangeiro A, Escuder MML, Castilho EA. Magnitude e tendência da epidemia de Aids em municípios brasileiros de 2002-2006. Rev Saúde Pública. 2010;44(3):430-41.

7. Word Health Organization. UNAIDS/OMS. Global Report: UNAIDS report on the global aids epidemic. [Internet]. 2012. [acesso 10 dez 2012] Disponível em: http://www.unaids.org/en/media/unaids/contentassets/ documents/epidemiology/2012/gr2012/20121120_ UNAIDS_Global_Report_2012_en.pdf

8. University of New Mexico Health Sciences Center. AIDSinfonet. Older people and HIV [Internet]. Fact Sheet Number 616. 2012 [acesso 22 mar de 2013]. Disponível em: http://www.aidsinfonet.org/ fact_sheets/view/616

9. Centre for Communicable Diseases and Infection Control. Public Health Agency of Canada [Internet]. HIV/AIDS among older Canadians. 2010. [acesso 15 mar 2013]. Disponível em: http://www.phac-aspc. gc.ca/aids-sida/publication/epi/2010/6-eng.php
10. Ministério da Saúde (BR). Boletim epidemiológico Aids, DST.ano 2(1). Brasília: Secretaria de vigilância em saúde. Departamento de Aids, DST e Hepatites Virais; 2013.

11. Fry PH, Monteiro S, Maio MC, Bastos FI, Santos RV. AIDS tem cor ou raça? Interpretação de dados e formulação de políticas de saúde no Brasil. Cad Saúde Pública. 2007;23(3):497-523.

12. Fonseca MGP, Szwarcwald CL, Bastos FI. Análise sociodemográfica da epidemia de Aids no Brasil, 19891997. Rev Saúde Pública. 2002;36(6):678-85.

13. Szwarcwald CL. A Disseminação da Epidemia de Aids no Brasil no Período de 1987-1996: Uma Análise Espacial. Cad Saúde Pública. 2000;16(11):135-41.

14. Instituto Brasileiro de Geografia e Estatística [Internet]. Censo Demográfico 2010. [acesso 30 mar 2013] Disponível em: http://www.ibge.gov.br

15. Ministério da Saúde (BR) [Internet]. Plano de Enfrentamento de Feminização 2009 (revisado). [acesso 20 mai 2012] Disponível em: http://sistemas.aids.gov. $\mathrm{br} /$ feminizacao/index.php?q=plano-de-enfrentamentoda-feminização

16. Parker R, Camargo KR Junior. Pobreza e HIV/AIDS: aspectos antropológicos e sociológicos. Cad Saúde Pública. 2000;16(supl 1):89-102.

17. Cavalcanti LF, Gomes R, Minayo MCS. Representações Sociais de profissionais de saúde sobre violência sexual contra a mulher: estudo em três maternidades públicas municipais do Rio de Janeiro, Brasil. Cad Saúde Pública. 2006;22(1):31-9.

18. Santos $V L$, Bermúdez XP, Toledo LM, Cruz MM, Moreira E. Reflexões sobre as políticas de controle das DST e Aids na população indígena. Tempus Actas em Saúde Coletiva. 2010;4(2):89-100.

19. Linley L, Hall HI, An Q, Wheeler W. HIV/AIDS diagnoses among persons fifty years and older. In 33 states, 2001-2005. National HIV Prevention Conference, Abstract. Atlanta; December 2007. B08-1.

20. Toledo LSG, Maciel ELN, Rodrigues LCM, Tristão-Sá R, Fregona G. Características e tendência da AIDS entre idosos no Estado do Espírito Santo. Rev Soc Bras Med Trop. 2010;43(3):264-7.

21. Bertoni FR, Bunn K, Silva J, Traebert J. Perfil Demográfico e Socioeconômico dos Portadores de HIV/ Aids do Ambulatório de Controle de DST/AIDS de São José. Arq Catarinenses Med. 2010;39(4):75-9.

22. Feitoza AR, Souza AR, Araújo MFM. A magnitude da infecção pelo HIV-AIDS em maiores de 50 anos no município de Fortaleza (CE). DST - J Bras Doenças Sex Transm. 2004;16(4):32-7. 
23. Brasileiro M, Freitas MIF. Social representations about aids in people over 50, infected by HIV. Rev. Latino-Am. Enfermagem. 2006;14(5):789-75.

24. Hagget $P$. The geographical structure of epidemics. Oxford: Oxford University Press; 2000. 